\section{Review}

Correspondence

John Bullen

john.bullen@tiscali.fr

\title{
Natural resistance, iron and infection: a challenge for clinical medicine
}

\author{
John J. Bullen, ${ }^{1,2}$ Henry J. Rogers, ${ }^{1}$ Paul B. Spalding ${ }^{2}$ and C. Gillon Ward ${ }^{1,2}$ \\ ${ }^{1}$ National Institute for Medical Research, Mill Hill, London NW7 1AA, UK \\ ${ }^{2}$ Department of Surgery, School of Medicine, University of Miami, PO Box 016310, Miami, \\ FL 33101, USA
}

\begin{abstract}
Natural resistance to infection, which does not depend on antibiotics, is a powerful protective mechanism common to all mankind that has been responsible for the survival of our species during countless millennia in the past. The normal functioning of this complex system of phagocytic cells and tissue fluids is entirely dependent on an extremely low level of free ionic iron $\left(10^{-18} \mathrm{M}\right)$ in tissue fluids. This low-iron environment is maintained by the unsaturated iron-binding proteins transferrin and lactoferrin, which depend on well-oxygenated tissues, where a relatively high oxidation-reduction potential (Eh) and $\mathrm{pH}$ are essential for the binding of ferric iron. Freely available iron is derived from iron overload, free haem compounds, or hypoxia in injured tissue leading to a fall in Eh and $\mathrm{pH}$. This can severely damage or abolish normal bactericidal mechanisms in tissue fluids leading to overwhelming growth of bacteria or fungi. The challenge for clinical medicine is to reduce or eliminate the presence of freely available iron in clinical disease. In injured or hypoxic tissue, treatment with hyperbaric oxygen might prove very useful by increasing tissue oxygenation and restoring normal bactericidal mechanisms in tissue fluids, which would be of huge benefit to the patient.
\end{abstract}

\section{Introduction}

The rapid increase in bacterial resistance to antibiotics has resulted in increased morbidity and mortality among patients in hospitals, and in intensive care units in particular. Various measures have been proposed for alleviating this situation, such as increased surveillance, improved physical controls like hand washing, and the substitution of empirically employed broad-spectrum antibiotics by narrow-spectrum drugs to which the infecting organism is known to be sensitive (Vincent et al., 2004). These and other measures can be used as a concerted attempt to stop a process that yearly has been getting worse. However, experience suggests that bacterial resistance to antibiotics will continue to increase for as long as the use of antibiotics provides the selective pressure (National Institute of Allergy and Infectious Diseases, 2004; Murray, 2000). In that case what is to be done? Is there any system of infection control that does not involve antibiotics? The answer is yes, and this system has been with us for a very long time.

Natural resistance to infection has been responsible for the survival of our species, in spite of repeated attacks by bacteria. Infections like bubonic plague, syphilis, tuberculosis, cholera, and many others, have resulted in many casualties, but always there have been survivors capable of passing on their mechanisms of resistance to future generations.

The protective systems of natural resistance need to be exploited in various different ways, but one single fact is paramount: the ability of the complex system of phagocytic cells and tissue fluids to resist bacterial invasion depends entirely on an extremely low level of free ionic iron (about $10^{-18} \mathrm{M}$ ) in tissue fluids such as plasma. This low-iron environment is due to the iron-binding proteins transferrin and lactoferrin, which are normally only $30-40 \%$ saturated with iron and have very high association constants for ferric iron of about $10^{36}$ (Bullen et al., 1978, 2005). Freely available iron can severely damage or destroy the whole mechanism of natural resistance, leading to rapid bacterial or fungal growth in tissue fluids. In addition, it is essential that normal physiological conditions in tissue fluids, such as the $\mathrm{pO}_{2}, \mathrm{pH}$ and the oxidation-reduction potential (Eh), are taken into account since these physical conditions are closely involved in controlling the availability of iron for bacteria (Bullen et al., 2005).

There are three main sources of free iron during clinical infections. First, iron overload due to altered metabolism, such as during haemochromatosis and hepatic disease, cancer or following chemotherapy. Second, iron from free haem compounds following the lysis of red cells. Third, iron made available from normal fluids and tissues as a result of trauma and altered physiological conditions.

There are ample data to show that the availability of iron can and does play a critical role in many different clinical infections. This represents a challenge for clinical medicine to investigate the role of iron availability more closely. At 
present there appears to be a general unawareness of the relevance of this topic for clinical medicine, and its close involvement in bacterial invasion and host resistance. Continuing problems with antibiotics make it more urgent than ever to explore new methods of enhancing natural resistance. If successful this could be of great benefit, not least because no antibiotics are involved.

\section{Infections with iron overload}

Haemochromatosis and hepatic disease. Patients with haemochromatosis or severe hepatic disease have abnormal levels of stored iron. Normally persons possess $1-2 \mathrm{~g}$ of iron. In haemochromatosis the range is $8-37 \mathrm{~g}$, much of it stored in the liver. In these patients there is often an abnormally high level of saturation of serum transferrin with iron (McLaren et al., 1983), and there may also be a pool of freely available low molecular mass iron in the plasma, detectable by the bleomycin assay, that is not present in normal persons (Gutteridge et al., 1985).

Patients with haemochromatosis and other syndromes involving iron overload are unusually susceptible to Vibrio vulnificus infections. This organism lacks an efficient highaffinity iron-uptake system, and cannot grow in inactivated (complement free) normal human serum (Chart \& Griffiths, 1985) It is easily destroyed by fresh human plasma, but multiplies rapidly in the plasma of haemochromatosis patients with high levels of freely available iron (Bullen et al., 1991).

$V$. vulnificus septicaemia is one of the most striking examples of enhanced susceptibility to infection. It begins abruptly without any apparent focus of infection and often follows the eating of raw sea food such as oysters. Of 24 patients with primary septicaemia, 18 had pre-existing hepatic disease, including haemochromatosis, chronic cirrhosis and hepatitis. Of the remaining six, three had a history of alcoholism, one of thalassaemia, one had diabetes, and one had no underlying disease (Blake et al., 1979). V. vulnificus was isolated from the blood of all 18 cases of primary septicaemia (Tacket et al., 1984). Wound infections are often related to contamination with sea water but are not statistically related to any chronic disease (Blake et al., 1979).

\section{Acute leukaemia and Candida albicans infection.} Acute leukaemia is often accompanied by iron overload, and patients are unusually susceptible to C. albicans infection. Caroline et al. (1969) found a high incidence of raised serum iron in patients with acute leukaemia. Of 34 patients with acute myeloid leukaemia, 21 had high serum iron $\left(>120 \mu \mathrm{g} \mathrm{dl}^{-1}\right)$ and 17 had fully saturated transferrin (two of these patients had systemic candidiasis). Another 10 patients had a transferrin saturation of over $50 \%$. C. albicans grew profusely in the serum of patients with acute leukaemia when the serum transferrin was $100 \%$ saturated with iron. The fungus was inhibited by serum with a normal $30 \%$ saturation, but this inhibition was abolished by adding iron to give $100 \%$ saturation. In addition, it was shown that leukaemic serum plus serum with a high unsaturated iron-binding capacity became inhibitory to the fungus, and that this inhibition could be reversed by adding iron. The same effects were produced using purified human transferrin. Nobody has ever questioned these results, which strongly suggest that the reason for the increased susceptibility of leukaemic patients to $C$. albicans infection is that the fungus is capable of rapid multiplication in tissue fluids containing freely available iron. More recent work has shown that two high-affinity iron permease genes are essential virulence factors in $C$. albicans (Ramanan \& Wang, 2000).

Chemotherapy increases iron availability. Chemotherapy can increase levels of freely available iron. One study showed that 70 patients with acute leukaemia had raised levels of transferrin saturation (50-59\%) before treatment. This was increased to $96 \%$ or above after treatment with cytosine arabinoside and daunorubicin together with granulocytopenia $\left(<1000\right.$ cells $\left.\mu \mathrm{l}^{-1}\right)$.There was also a significant fall in total iron-binding capacity. Fungal infections were suspected in $59 \%$ of these patients and confirmed in $19 \%$ (Karp \& Metz, 1986). In addition some patients with myeloid leukaemia have circulating low molecular mass iron complexes of about $1 \cdot 0 \mu \mathrm{mol} 1^{-1}$, which were increased to about $9 \cdot 0 \mu \mathrm{mol} \mathrm{l}^{-1}$ after chemotherapy (Halliwell et al., 1988).

In another example, six patients with cancers varying from gastric adenocarcinoma to non-Hodgkins lymphoma developed high serum iron within 7 days of starting chemotherapy. Serum iron rose from approximately 77 to $226 \mu \mathrm{g}$ $\mathrm{dl}^{-1}$, and transferrin saturation from approximately 33 to $97 \%$. In 12 patients with acute non-lymphocytic leukaemia, the transferrin saturation ranged from 22 to $105 \%$ before treatment. After starting treatment, the saturation rose sharply in 8 out of 9 patients and reached $>90 \%$ in all the patients at some time during the observation period of 40 days (Gordeuk et al., 1986). Thus, both leukaemia (Caroline et al., 1969) and chemotherapy (Karp \& Metz., 1986) are frequently accompanied by severe iron overload. Since normal human serum is inhibitory for many pathogenic fungi (King et al., 1975; Sutcliffe et al., 1980), including C. albicans (Caroline et al., 1969) and Rhizopus arrhizus (Boelaert et al., 1993), and since this inhibition is abolished by free iron, it seems highly likely that the removal of this antifungal mechanism is the main reason for the increased susceptibility of patients with leukaemia and those undergoing chemotherapy.

Mucormycosis following treatment with deferoxamine. Boelaert et al. (1993) showed that the iron chelate deferoxamine can act as a siderophore for pathogenic fungi. It promotes mucormycosis in guinea pigs infected with Rhizopus microsporus, $R$. arrhizus (formerly called Rhizopus oryzae), Aspergillus fumigatus and Cryptococcus neoformans, but had no significant effect on C. albicans infections. It abolished the inhibitory effect of human serum 
on $R$. microsporus, and promoted the growth and iron uptake of $R$. microsporus and $R$. arrhizus in human serum. The increased susceptibility of dialysis patients to mucormycosis compared with patients with normal renal function when treated with deferoxamine was explained by the fact that uremia results in sufficient retention of the iron-loaded siderophore to reverse the fungistatic power of normal serum.

Mucormycosis in diabetic ketoacidosis. Diabetic ketoacidosis may be defined as a condition where patients have positive serum ketones and an arterial blood $\mathrm{pH}$ of $7 \cdot 3$ or less and/or a serum bicarbonate of $15 \mathrm{mmole}^{-1}$ or less (Lebovitz 1995; Artis et al., 1982). Artis et al. (1982) showed that normal human serum equilibrated with $\mathrm{CO}_{2}$ to give a $\mathrm{pH}$ of $7 \cdot 4$ was inhibitory to $R$. oryzae. Adding extra glucose made no difference, but when the $\mathrm{pH}$ was adjusted to $7 \cdot 3$ or below profuse growth of the fungus occurred. In addition, lowering the $\mathrm{pH}$ of normal serum from $\mathrm{pH} 7 \cdot 4$ to 6.35 progressively reduced its ironbinding capacity. When diabetic sera were tested at their clinical $\mathrm{pH}(6 \cdot 88-7 \cdot 21)$ four out of seven produced profuse growth of the fungus. The remaining three were inhibitory but found to be very low in iron $\left(1-27 \mu \mathrm{g} \mathrm{dl}^{-1}\right)$. Tests with one of these sera to which iron was added showed that profuse growth occurred at $\mathrm{pH} 7 \cdot 08$, but no growth at $\mathrm{pH} 7 \cdot 4$ unless the transferrin was saturated. These results suggest that increased availability of iron during ketoacidosis following a fall in $\mathrm{pH}$ is the basic reason for the increased susceptibility of uncontrolled diabetic patients to mucormycosis. The $\mathrm{pH}$ is also critical with other fungi. For example, reducing the $\mathrm{pH}$ to $6 \cdot 6$ abolished the inhibitory effect of human serum against Histoplasma capsulatum (Sutcliffe et al., 1980).

Thalassaemia and splenectomy. Thalassaemia is characterized by severe iron overload and increased susceptibility to infection (Hershko et al., 1988). Splenectomy greatly increases the risk in thalassemic patients but this has little effect in normal persons. Thus the rate of infection in 1358 normal persons where splenectomy was performed following trauma was $1.5 \%$, but $7 \%$ in 185 thalassaemia patients (Holdsworth \& Cuschieri, 1991). In another 688 patients splenectomised after trauma the incidence of infection was $1.5 \%$, but $25 \%$ in 109 patients with thalassaemia (Singer, 1973).

The incidence of severe infections after splenectomy depends very much on the underlying condition of the patient. There appears to be little risk of infection following splenectomy for trauma, idiopathic thrombocytopenic purpura, extrahepatic portal vein thrombosis, portal hypertension or localized tumours, but a high risk of fatal infections if splenectomy is accompanied by thalassaemia major, hepatitis, cirrhosis, Wiskott-Aldrich syndrome, histiocytosis or inborn errors of metabolism (Eraklis et al., 1967).

One of the significant aspects of thalassaemia is that iron overload is greatly increased by splenectomy. Forty-six patients with $\mathrm{HbH}$ (haemoglobin $\mathrm{H}$ ) disease had a transferrin saturation of about $61 \%$ compared with about $36 \%$ in normal controls. In 84 patients with $\operatorname{HbE}$ ( $\beta$-thalassaemia) disease the mean saturation was about $67 \%$, which rose to $90 \%$ after splenectomy. Among all 130 patients there were 30 with $100 \%$ saturation of their serum transferrin (Pootrakul et al., 1980). Thalassaemic patients also had circulating nontransferrin-bound iron, which was increased by about fourfold after splenectomy (Anuwatanakulchai et al., 1984).

It has been suggested that an increased susceptibility to infection after splenectomy is due to a reduced primary and secondary response to antigens, and a reduced clearance of blood-borne bacteria (Hershko et al., 1988). This is unlikely to be true if splenectomy has little effect following trauma (Holdsworth \& Cuschieri, 1991; Singer, 1973), since the same ill effects of splenectomy should apply to trauma patients. Thus, the increase in iron overload following splenectomy of thalassaemic patients has similar consequences to that following leukaemia and chemotherapy except that bacterial infections, particularly of Streptococcus pneumoniae, predominate in thalassaemia (Holdsworth \& Cuschieri, 1991), and fungal infections predominate in leukaemia (Caroline et al., 1969).

\section{Neutropenia and iron overload}

In a recent review on fungal infections in neutropenic patients, by Groll \& Walsh (2003), it was assumed that neutropenia was the sole cause of the patients' increased susceptibility to fungal infection. No mention is made of the work of Caroline et al. (1969) or Boelaert et al. (1993) that has shown quite clearly that freely available iron is critically involved in the process. If neutropenia were the sole cause of increased susceptibility one would expect that an increase in the number of polymorphs induced by granulocyte colony stimulating factors would be beneficial. In one case, 4-5 days of treatment gave increased levels of granulocytes, varying from three to eight times base levels, but the authors point out that it was difficult to prove that shorter periods of neutropenia or raised levels of cells were of benefit to the patient (Lieschke \& Burgess., 1992). In another instance an increase in neutrophils produced by granulocyte colony stimulating factors failed to demonstrate any significant effect on overall survival or disease-free survival (Dale, 2002). In the review by Groll \& Walsh (2003), there was no evidence to show that granulocyte colony stimulating factors were of definite clinical value. It may also be significant that patients with pulmonary aspergillosis who had recovered from neutropenia but required further chemotherapy or allogenic cell transplantation had an increased risk of exacerbation of the infection (Groll \& Walsh., 2003).

\section{Possible treatment of iron overload}

As far as we are aware no adequate clinical trials have yet been made of any method for reducing the iron overload in patients with acute leukaemia, with a view to restoring their normal resistance to infection. This might be done by 
treatment with apotransferrin or apolactoferrin, where some observations have suggested that apotransferrin might be useful. Its use prevented the growth of Staphylococcus epidermidis in the serum of stem cell transplant patients by binding free iron (Bonsdorf et al., 2003). Tests with two patients showed that apotransferrin could reduce the level of iron saturation from $80-90 \%$ to about $30 \%$ in $12-14$ days. Among 20 patients this made no significant difference in the incidence of septic infections compared with controls, but because of these small numbers it is clear that more data are required to assess the true value of reducing iron overload by this means.

Another possibility is to use interleukin-1. Human recombinant interleukin-1 had a powerful effect in rats causing a fall in serum iron from 184 to $24 \mu \mathrm{g} \mathrm{dl}^{-1}$ (87\% fall) in $6 \mathrm{~h}$ followed by a slow recovery that was not complete after $24 \mathrm{~h}$. This was accompanied by a well-marked neutrophilia (Uchida et al., 1991). Thus treatment with interleukin-1 would probably provoke many of the other responses associated with fever, but it has the advantage that it is a natural product involved in normal human physiology. It may therefore be safe to use for treatment in spite of its multiple effects.

\section{The importance of haem compounds}

Free haemoglobin and derived compounds such as haematin readily provide iron for bacteria (Griffiths \& Williams, 1999), and are extremely effective in abolishing natural resistance to infection (Ward \& Bullen, 1999). Thus ferric iron, lysed red cells or haematin, were each capable of reducing the lethal intraperitoneal dose of Escherichia coli O111 for normal guinea pigs from approximately $1 \times 10^{8}$ to approximately $1 \times 10^{4}$ bacteria, an increase in virulence of approximately 10000 -fold (Bullen et al. 1968a). In addition, both lysed red cells and haematin completely abolished the protective effect of specific antibody against 'Pasteurella septica' in mice. In unprotected mice the bacteria grew rapidly to reach viable counts of over $10^{9}$ cells $^{-1}$ in moribund animals. All the passively immunized animals survived with low bacterial counts that persisted for several days. In passively immunized mice given haematin, protection was abolished and the bacterial counts were identical to those seen in unprotected normal animals. Almost identical results were obtained using lysed mouse cells (Bullen et al., 1968b). It must be emphasized that these overwhelming infections occur in the intact animal where all the cellular phagocytic systems are in place. The cells appear to be overwhelmed by rapid bacterial growth in the extracellular plasma. The same applies to the effect of iron compounds on E. coli infections in guinea pigs (Bullen et al., 1968a). Free ferric iron, even in relatively high concentrations $(2 \cdot 2 \mathrm{mM} \mathrm{Fe})$ does not affect the destructive power of polymorphonuclear leukocytes. This occurred only if the cells were exposed to a ferritinantiferritin complex where iron entered the cell and saturated the iron-binding capacity of the lactoferrin present with subsequent internal growth Pseudomonas aeruginosa or E. coli (Bullen \& Griffiths, 1999).
Blood transfusions. In terms of clinical medicine, it is important to emphasize that normal human plasma contains only $0 \cdot 3-0 \cdot 7 \mathrm{mg} \mathrm{dl}^{-1}$ of free haemoglobin (Levere et al., 1979). Even this small amount may be caused by damaging some red cells while taking the sample, and the true value may be zero. Any artificial increase in free haemoglobin would be expected to increase susceptibility to infection. Thus blood transfusions, particularly of allogenic cells, may be responsible for this (Ward \& Bullen, 1999). In a recent study from an intensive care unit the infection rate among 416 patients transfused with allogenic packed red cells was $15 \cdot 38 \%$ compared with $2.92 \%$ among 1301 non-transfused patients $(P<0 \cdot 005)$. There was also a well-marked dose-response pattern. The more red cell units transfused, the greater the chance of infection $(P<0 \cdot 0001)$ (Taylor et al., 2002). There are many similar articles of this nature, too numerous to discuss in detail, but in general terms it has been reported that transfusion with packed red blood cells increased the risk of ventilatorassociated pneumonia in intensive care units (Shorr et al., 2004), and that blood transfusion is an important independent statistical predictor of infection (Agarwal et al., 1993).

This increased susceptibility to infection is often attributed to immune suppression, but there is no certain evidence for this. However, there is no denying that free haem compounds definitely promote infection and the increased availability of iron from the lysis of transfused red cells may be the prime reason for this. This could be augmented by the low molecular mass iron complexes, detectable by the bleomycin assay, that occur in plasma-depleted red blood cell units stored for more than 10 days without haemolysis. (Marwah et al., 2002). In practice, it might be useful to measure the level of free haemoglobin and bleomycin iron in the plasma of transfused patients (Levere et al., 1979; Marwah et al., 2002), to assess the potential risk of circulating free iron.

Blood substitutes. The proposed benefits of blood substitutes based on modified haemoglobin are freedom from infectious agents and the ability to transport oxygen. Unfortunately, modified human haemoglobin is just as effective as native haemoglobin in promoting infection. Intraperitoneal injection of $10^{3} \mathrm{E}$. coli $\mathrm{O} 18 \mathrm{~K} 1$ into mice resulted in a brief invasion of the blood stream, but the organisms later disappeared and all the animals survived. Animals given $30 \mathrm{mg}$ pyridoxalated glycolaldehydepolymerized human haemoglobin, immediately before intraperitoneal infection with the same number of organisms, died from septicaemia with bacterial blood counts reaching $10^{8} \mathrm{ml}^{-1}$ (Griffiths et al., 1995).

In a clinical trial where patients suffering from severe haemorrhagic shock were given $500-1000 \mathrm{ml} 10 \%$ diaspirin cross-linked haemoglobin the death rate after 28 days was $46 \%$ compared with $17 \%$ in those given saline $(P=0 \cdot 003)$. Although the exact reasons for the increased mortality are not given it is clear that the haemoglobin solution was not a 
suitable resuscitation fluid (Sloan et al., 1999). It therefore seems certain that the idea of using free haem compounds as a blood substitute must be abandoned unless some satisfactory way can be found to enclose the material in artificial cells.

\section{Trauma, iron availability and infection}

The role of Eh and $\mathrm{pH}$ in bacterial growth in vivo. It has long been known that normal well-vascularized tissues are highly resistant to infection, and the key to this is adequate oxygenation. Hypoxia is known to favour infection (Hopf et al., 1997). This increased susceptibility to infection is usually attributed to interference with the oxidative killing of bacteria by polymorphonuclear leukocytes (Hopf et al., 1997). This may be true for some bacteria like staphylococci where the percentage of bacteria killed under anaerobic conditions was only $25 \%$ compared with $85 \%$ with air. However, this does not apply to some organisms like Pseudomonas aeruginosa or 'Streptococcus viridans', where anaerobic killing was identical to that seen under aerobic conditions, while for others like Clostridium perfringens or Bacteroides fragilis, the reduction in killing under anaerobic conditions was only slight (5$10 \%$ ) (Mandell, 1974). It therefore seems unlikely that the effects of hypoxia can be attributed entirely to a general depression of phagocyte killing against all the different organisms encountered in sepsis. However, hypoxia does have an indirect but profound influence on the availability of iron for bacteria by producing abnormal physical conditions in tissue fluids leading to freely available iron.

In normal well-oxygenated guinea pig muscle the Eh is about $+300 \mathrm{mV}$, pH 7·4. Under these conditions the iron bound to transferrin is in the ferric form with an iron saturation of about $30 \%$. This ensures the extremely low concentration of free ferric iron in tissue fluids such as plasma (about $10^{-18} \mathrm{M}$ ), which is essential for natural resistance to infection (Bullen et al., 2005). The Eh and $\mathrm{pH}$ of tissue fluids are immensely important since they govern the binding of iron to the protein, which can directly influence bacterial growth. If the Eh falls to $-140 \mathrm{mV}$ or below the iron is reduced to the ferrous form and is no longer bound by transferrin. It is then available to the bacteria (Rogers, 1967). The bactericidal effect of human plasma against $E$. coli was abolished by lowering the Eh from approximately +200 to $-400 \mathrm{mV}$ with a reducing agent. Ferrous iron was detected in the reduced plasma. The bactericidal effect was restored by introducing air into the system and raising the Eh from approximately -400 to $+200 \mathrm{mV}$. This shows that exposure to a low Eh does not permanently damage the bactericidal system and that bacterial killing can be switched on or off simply by adjusting the Eh (Bullen et al., 1992). The same applies to the $\mathrm{pH}$ of the system whereby the binding of iron by transferrin is progressively lost as the $\mathrm{pH}$ and the concentration of bicarbonate ion both fall (Lestas, 1976; Evans et al., 1999). This is accompanied by the loss of bactericidal effects against many different organisms (Bullen \& Griffiths, 1999).
The dramatic effect of lowering the $\mathrm{pH}$ in abolishing the inhibitory power of serum against $R$. oryzae has already been mentioned. In addition, hypoxia may result in glycolysis and the appearance of lactic acid, which will lead to a fall in tissue $\mathrm{pH}$.

The significance of bacterial reducing systems. An important aspect of infection is the reducing power of bacteria, which is essential for establishing growth in vivo. Bacteria bring about reduction as a natural result of metabolic activity. To obtain the energy necessary for proliferation substrates like glucose must be oxidized, and for this purpose free oxygen, combined oxygen, hydrogen acceptors or any suitable type of oxidizing agent will be used by the cell. The intense reducing capabilities of some bacteria are illustrated by E. coli, where fifteen million molecules of oxidant may be reduced by one cell in 1 min (Hewitt, 1950).

Hypoxia favours infection and this is dramatically illustrated by the remarkable power of adrenaline to promote bacterial virulence. In skin infections in guinea pigs the injection of $2 \mu \mathrm{g}$ adrenaline greatly promoted infection with some bacteria. There was a 100000 -fold reduction in the minimum infecting dose of Clostridium septicum and $\mathrm{Cl}$. perfringens, 10000 -fold with E. coli, 60-80-fold with staphylococci, tenfold with Streptococcus pneumoniae, but none with Vibrio cholerae (Evans et al., 1947). One may ask why the injection of adrenaline should produce such different results with different bacteria. However, adrenaline produces a fall in tissue Eh $(-28$ to $-58 \mathrm{mV})$ as a result of ischaemia, and the most likely explanation for the varying enhancement of virulence is that bacteria differ greatly in their reducing power. Thus, bacteria like $\mathrm{Cl}$. perfringens or E. coli, which have very powerful reducing systems capable of reducing the Eh of the medium to $-400 \mathrm{mV}$ or below, may be able to take advantage of a reduction in skin Eh to -28 to $-58 \mathrm{mV}$ to greatly reduce the number of bacteria necessary for rapid multiplication. Other organisms like Staphylococcus aureus have far less powerful reducing systems (Hewitt, 1950) and may be less capable of taking advantage of a reduction in skin Eh. Also, bacteria with powerful reducing systems may be better equipped to lower the Eh of tissue fluids below the critical level of $-140 \mathrm{mV}$ where ferrous iron would be freely available and capable of stimulating rapid bacterial growth (Rogers, 1967).

The reducing power of bacteria can have major consequences in vivo. Experiments with $\mathrm{Cl}$. perfringens in passively immunized animals showed that highly reducing conditions produced by these organisms in peritoneal exudates (approximately $-400 \mathrm{mV}, \mathrm{pH} 6 \cdot 4$ with no free oxygen present) caused a large increase in vascular permeability leading to hypovolaemic shock and death. The exudates were otherwise non-toxic but contained large amounts of protein. Here it was noticeable that relatively high oxygen tensions could be maintained in the dorsal muscles accompanied by a zero oxygen tension and a very low Eh (approximately $-400 \mathrm{mV}$ ) in the peritoneal fluid (Bullen 
et al., 1966). In man, a fall in oxygen tension below 2000$3333 \mathrm{~Pa}$, corresponding to an oxygen saturation of 15-25\% in those with a normal haemoglobin content, is required to produce an increase in vascular permeability in the small vessels of the arm. However, increased permeability will occur if the oxygen tension falls below this value, even for a short period (Henry et al., 1947).

In septic peritonitis in man it has been shown that the mean $\mathrm{pH}$ in drainage fluid from 59 patients was 6.75 compared with $7 \cdot 49$ in 105 uninfected patients. The $\mathrm{pO}_{2}$ in 17 infected patients was zero or near zero (Simmen \& Blaser, 1993). Unfortunately, a zero $\mathrm{pO}_{2}$ does not indicate if reducing conditions exist, and to explore this it would be essential to measure the $\mathrm{Eh}$ and $\mathrm{pH}$. Clinically it could be very important to know if highly reducing conditions existed in the peritoneal cavity of these patients.

Gas gangrene. Gas gangrene, following the infection of severe wounds by clostridia, and particularly $\mathrm{Cl}$. perfringens type $\mathrm{A}$, is a rapidly spreading myonecrosis and is characterized by a profound toxaemia and prostration (van Heyningen, 1955). During World War II it was generally believed that the alpha toxin of $\mathrm{Cl}$. perfringens was primarily responsible for the toxaemia. However, it was found that patients could have a large excess of circulating alpha antitoxin and yet continue to suffer from toxaemia. In nine cases an excess of antitoxin for as long as $92 \mathrm{~h}$ before death failed to prevent a fatal outcome (MacLennan \& MacFarlane, 1945). It was also a puzzle as to why the bacteria continued to invade antitoxin-containing muscle (Oakley, 1954).

It could be argued that the failure of the antitoxin to protect was because the toxin was rapidly bound to its substrate and access by antitoxin was prevented by mechanical factors. In that case nothing could be done to save the patient, but as van Heyningen (1955) pointed out, the patient could be saved by radical surgery, and the recovery that took place was 'dramatic, heartening, and instructive'. A source of poison had been removed and this did not seem to be the alpha toxin (van Heyningen, 1955).

The reason why the bacteria continued to invade antitoxincontaining muscle may be explained by the very low Eh (Oakley, 1954) in the infected tissue, which would result in the presence of freely available ferrous iron allowing rapid bacterial growth in the presence of normally protective antibody (Bullen et al., 1967). The toxaemia may be explained by the ability of a very low Eh and $\mathrm{pH}$ to increase vascular permeability in tissues with the production of fatal shock (Stoner et al., 1967). Both these influences would be removed by radical surgery leading to a rapid recovery, and healthy well-oxygenated tissue containing antitoxin would effectively prevent further spread of the disease. Specific antitoxin is bacteriostatic against $\mathrm{Cl}$. perfringens at a relatively high Eh of $+60 \mathrm{mV}, \mathrm{pH} 7 \cdot 4$, but this is abolished at an Eh of $-140 \mathrm{mV}, \mathrm{pH} 7 \cdot 4$ or below (Bullen et al., 1964).

\section{Is hyperbaric oxygen the answer?}

Adequate oxygenation of tissues is essential for natural resistance to infection (Bullen et al., 2005; Hopf et al., 1997). Clinical experience has shown that increasing the concentration of inspired oxygen to $80 \%$ in patients undergoing colorectal resection, and for $2 \mathrm{~h}$ thereafter, halved the incidence of infection compared with patients receiving $30 \%$ oxygen (Grief et al., 2000). With hyperbaric oxygen the level of tissue oxygenation can be increased still further. This has many advantages and has been shown to be effective in many different infections, but it also has side effects that can be troublesome and cannot be ignored (Wang et al., 2003; Gottrup, 2004). Treatment with hyperbaric oxygen would be much more reliable if the $\mathrm{Eh}$ and $\mathrm{pH}$ of tissues were measured routinely, since this is the only means of telling if reducing conditions exist, or to observe if the Eh can be raised by increasing the oxygen tension. This is one of the most important aspects of infection since restoration of naturally occurring bactericidal systems in infected tissues by controlling the Eh and $\mathrm{pH}$ could be of huge benefit.

\section{Conclusions}

There is a chain of events in the susceptibility of human tissues to infection that largely or entirely depends upon the availability of freely available iron for the bacteria. Natural resistance to infection operates in an environment where the amount of freely available iron is extremely low. This depends very much on the physical conditions in tissue fluids where the Eh and $\mathrm{pH}$ govern the binding of iron to the unsaturated iron-binding proteins transferrin or lactoferrin. The Eh in turn depends on the degree of tissue oxygenation, and therefore hypoxia is of the greatest importance since it produces a fall in tissue Eh, which can result in the production of free ferrous iron and a huge stimulus to bacterial growth. Iron provided by free haem compounds is equally dangerous.

In clinical medicine it might be advantageous to concentrate on those aspects of natural resistance that can be manipulated without the use of antibiotics. This includes a reduction in iron overload during conditions such as acute leukaemia, and in patients undergoing chemotherapy. The use of blood transfusions and blood substitutes based on haemoglobin requires re-examination because these products are potentially dangerous. Finally there is the restoration of natural resistance in injured and infected tissues by increased oxygenation. Measurement and control of the Eh and $\mathrm{pH}$ would be essential, but it would be of the utmost value if the bactericidal mechanisms in infected tissues could be restored by purely physical means.

\section{References}

Agarwal, N., Murphy, J. G., Cayten, C. G. \& Stahl, W. M. (1993). Blood transfusion increases the risk of infection after trauma. Arch Surg 128, 171-176. 
Anuwatanakulchai, M., Pootrakul, P. \& Thuvasethakul, P. (1984). Non transferrin iron in B-thalassaemia/ $\mathrm{Hb}$ E and haemoglobin $\mathrm{H}$ diseases. Scand J Haematol 32, 153-158.

Artis, W. M., Fountain, J. A., Delcher, H. K. \& Jones, H. E. (1982). A mechanism of susceptibility to mucormycosis in diabetic ketoacidosis: transferrin and iron availability. Diabetes 31, 1109-1114.

Blake, P. A., Merson, M. H., Weaver, R. E., Hollis, D. G. \& Heublein, P. C. (1979). Disease caused by a marine vibrio. Clinical characteristics and epidemiology. $N$ Engl J Med 300, 1-5.

Boelaert, J. R., de Locht, M., van Cutsem, J., Kerrels, V., Cantinieaux, B., Verdonck, A., van Landuyt, H. W. \& Schneider, Y.-J. (1993). Mucormycosis during deferoxamine therapy is a siderophore mediated infection: in-vitro and in-vivo animal studies. J Clin Invest 91, 1979-1986.

Bonsdorf, L., von Sahlstedt, L., Ebeling, F., Ruutu, T. \& Parkkinen, J. (2003). Apotransferrin administration prevents growth of Staphylococcus epidermidis in serum of stemcell transplant patients by binding of free iron. FEMS Immunol Med Microbiol 37, 45-51.

Bullen, J. J. \& Griffiths, E. (1999). Iron binding proteins and host defence. In Iron and Infection. Molecular, Physiological and Clinical Aspects, 2nd edn, pp. 327-368. Edited by J. J. Bullen \& E. Griffiths. Chichester: Wiley.

Bullen, J. J., Dobson, A. \& Wilson, A. B. (1964). Bacteriostatic effects of specific antiserum on Clostridium welchii type A. The role of Eh and $\mathrm{pH}$ of the medium. J Gen Microbiol 35, 175-182.

Bullen, J. J., Cushnie, G. H. \& Rogers, H. J. (1967). Abolition of the protective effect of Clostridium welchii type A antiserum by ferric iron. Immunology 12, 303-312.

Bullen, J. J., Cushnie, G. H. \& Stoner, H. B. (1966). Oxygen uptake by Clostridium welchii type A, its possible role in experimental infections in passively immunised animals. Br J Exp Pathol 47, 488-506.

Bullen, J. J., Leigh, L. C. \& Rogers, H. J. (1968a). The effect of iron compounds on the virulence of Escherichia coli for guinea pigs. Immunology 15, 581-588.

Bullen, J. J., Wilson, A. B., Cushnie, G. H. \& Rogers, H. J. (1968b). The abolition of the protective effect of Pasteurella septica antiserum by iron compounds. Immunology 14, 889-898.

Bullen, J. J., Rogers, H. J. \& Griffiths, E. (1978). Role of iron in bacterial infection. Curr Top Microbiol Immunol 80, 1-35.

Bullen, J. J., Spalding, P. B., Ward, C. G. \& Gutteridge, J. M. C. (1991). Haemochromatosis, iron, and septicaemia caused by Vibrio vulnificus. Arch Intern Med 151, 1606-1609.

Bullen, J. J., Spalding, P. B., Ward, C. G. \& Rogers, H. J. (1992). The role of $\mathrm{Eh}, \mathrm{pH}$, and iron in the bactericidal power of human plasma. FEMS Microbiol Lett 94, 47-52.

Bullen, J. J., Rogers, H. J., Spalding, P. B. \& Ward, C. G. (2005). Iron and infection, the heart of the matter. FEMS Immunol Med Microbiol 43, 325-330.

Caroline, L., Rosner, F. \& Kozinn, P. J. (1969). Elevated serum iron, low unbound transferrin and candidiasis in acute leukaemia. Blood 34, 441-451.

Chart, H. \& Griffiths, E. (1985). The availability of iron and the growth of Vibrio vulnificus in sera from patients with haemochromatosis. FEMS Microbiol Lett 26, 227-231.

Dale, D. C. (2002). Colony-stimulating factors for the management of neutropenia in cancer patients. Drugs 62, 1-15.

Eraklis, A. J., Brammer, S. R., Diamond, L. K. \& Gross, R. E. (1967) Hazard of overwhelming infection after splenectomy in childhood. $N$ Engl J Med 267, 1225-1229.

Evans, D. G., Miles, A. A. \& Niven, J. S. F. (1947). The enhancement of bacterial infections by adrenaline. Br J Exp Pathol 29, 20-39.
Evans, R. W., Crawley, J. B., Joannou, C. L. \& Sharma, N. D. (1999). Iron proteins. In Iron and Infection. Molecular, Physiological, and Clinical Aspects, 2nd edn, pp. 27-86. Edited by J. J. Bullen \& E. Griffiths. Chichester: Wiley.

Gordeuk, V. R., Brittenham, G. M., McLaren, G. D. \& Spagnuolo, P. J. (1986). Hyperferraemia in immunosuppressed patients with acute nonlymphatic leukemia and the risk of infection. J Lab Clin Med 108, 466-472.

Gottrup, F. (2004). Oxygen in wound healing and infection. World J Surg 28, 312-315.

Grief, R., Akca, O., Horn, E.-P. \& Sessler, D. I. (2000). Supplemental perioperative oxygen to reduce the incidence of surgical wound infection. N Engl J Med 342, 161-167.

Griffiths, E. \& Williams, P. (1999). The iron-uptake systems of pathogenic bacteria, fungi and protozoa. In Iron and Infection. Molecular, Physiological, and Clinical Aspects, 2nd edn, pp. 87-212. Edited by J. J. Bullen \& E. Griffiths. Chichester: Wiley.

Griffiths, E., Cortes, A., Gilbert, N., Stevenson, P., MacDonald, S. \& Pepper, D. (1995). Haemoglobin-based blood substitutes and sepsis. Lancet 345, 158-160.

Groll, A. H. \& Walsh, T. J. (2003). Invasive fungal infections in the neutropenic cancer patient. Abstr Hematol Oncol 6, 18-26.

Gutteridge, J. M. C., Rowley, D. A., Griffiths, E. \& Halliwell, B. (1985). Low-molecular-weight complexes and oxygen radical reactions in idiopathic haemochromatosis. Clin Sci 68, 463-467.

Halliwell, B., Aruoma, O. I., Mufti, G. \& Bomford, A. (1988). Bleomycin detectable iron in serum from leukaemic patients before and after chemotherapy. FEBS Lett 241, 202-204.

Henry, J., Goodman, J., Meehan, J. \& Frankel, R. (1947). Capillary permeability in relation to acute anoxia and to venous oxygen saturation. J Clin Invest 26, 1119-1129.

Hershko, C., Peto, T. E. A. \& Weatherall, D. J. (1988). Iron and infection. BMJ 296, 660-664.

Hewitt, L. F. (1950). Oxidation-reduction Potentials in Bacteriology and Biochemistry, 6th edn, pp. 97-127. Edinburgh: E\&S Livingstone. Holdsworth, R. J., Irving, A. D. \& Cuschieri, A. (1991). Postsplenectomy sepsis and its mortality rate: actual versus perceived risks. Br J Surg 78, 1031-1038.

Hopf, H. W., Hunt, T. K., West, J. M., \& 9 other authors (1997). Wound tissue oxygen tension predicts the risk of wound infection in surgical patients. Arch Surg 132, 977-1004.

Karp, J. E. \& Metz, W. G. (1986). Association of reduced total iron binding capacity and fungal infections in leukemic granulocytopenic patients. J Clin Oncol 4, 216-220.

King, R. D., Kahn, H. A., Foye, J. C., Greenberg, J. H. \& Jones, H. E. (1975). Transferrin, iron and dermatophytes. 1. Serum dermatophyte inhibitory component definitively identified as unsaturated transferrin. J Lab Clin Med 86, 204-212.

Lebovitz, H. E. (1995). Diabetic ketoacidosis. Lancet 345, 767-772.

Lestas, A. N. (1976). The effect of $\mathrm{pH}$ on human transferrin, selective labelling of the two iron-binding sites. Br J Haematol 32, 341-350.

Levere, R. D., Swerdlow, F. \& Garaway, M. R. (1979). Measurement of human plasma haemoglobin by difference spectrophotometry. J Lab Clin Med 77, 168-176.

Lieschke, G. J. \& Burgess, A. W. (1992). Granulocyte colony stimulating factor and granulocyte-macrophage colony-stimulating factor. $N$ Engl J Med 327, 28-35.

MacLennan, J. D. \& MacFarlane, R. W. (1945). Toxin and antitoxin studies of gas gangrene in man. Lancet 2, 62-66.

Mandell, G. I. (1974). Bactericidal activity of aerobic and anaerobic polymorphonuclear neutrophils. Infect Immun 9, 337-341. 
Marwah, S. S., Blann, A., Harrison, P., Lumley, M. A., Wright, J., McDowell, J., Phillips, J. D., Rea, C. \& Bareford, D. (2002). Increased non-transferrin bound iron in plasma-depleted SAG-M red blood cell units. Vox Sang 82, 122-126.

McLaren, G. D., Muir, W. A. \& Kellermeyer, R. W. (1983). Iron overload disorders, natural history, pathogenesis, and therapy. Crit Rev Clin Lab Sci 19, 205-266.

Murray, B. E. (2000). Vancomycin resistant enterococcal infections. $N$ Engl J Med 342, 710-721.

National Institute of Allergy \& Infectious Diseases (2004). Fact Sheet: The Problem of Antibiotic Resistance. http://www.niaid.nih.gov/ factsheets/antimicro.htm

Oakley, C. L. (1954). Gas gangrene. Br Med Bull 10, 52-58.

Pootrakul, P., Rugkiatsakul, R. \& Wasi, P. (1980). Increased transferrin saturation in splenectomised thalassemic patients. $\mathrm{Br}$ J Haematol 46, 143-145.

Ramanan, N. \& Wang, Y. (2000). A high affinity iron permease essential for Candida albicans virulence. Science 288, 1062-1064.

Rogers, H. J. (1967). Bacteriostatic effects of horse sera and serum fractions on Clostridium welchii type A, and the abolition of bacteriostasis by iron salts. Immunology 12, 285-301.

Shorr, A. F., Duh, M.-S., Kelly, K. M. \& Kolief, M. H. (2004). Red blood cell transfusion and ventillator-associated pneumonia, a potential link? Crit Care Med 32, 666-674.

Simmen, H.-P. \& Blaser, J. (1993). Analysis of $\mathrm{pH}$ and $\mathrm{pO}_{2}$ in abscesses, peritoneal fluid, and drainage fluid in the presence or absence of bacterial infection during and after abdominal surgery. Am J Surg 163, 24-27.

Singer, D. B. (1973). Postsplenectomy sepsis. Perspect Pediatr Pathol 1, 285-311.

Sloan, E. P., Koenigsberg, M., Gens, D., Cipolle, M., Runge, J., Mallory, M. N. \& Rodman, G., Jr (1999). Diaspirin cross-linked hemoglobin (DCLHb) in the treatment of severe haemorragic shock: a randomised controlled efficacy trial. JAMA 282, 1857-1864.

Stoner, H. B., Bullen, J. J., Cushnie, G. H. \& Batty, I. (1967). Fatal intraperitoneal infection with Clostridium welchii type A in passively immunised guinea-pigs. The effect on vascular permeability. Br J Exp Pathol 48, 309-318.

Sutcliffe, M. C., Savage, A. M. \& Alford, R. H. (1980). Transferrindependent growth inhibition of yeast-phase Histoplasma capsulatum by human serum and lymph. J Infect Dis 142, 209-219.

Tacket, C. O., Brenner, F. \& Blake, P. A. (1984). Clinical features and an epidemiological study of Vibrio vulnificus infections. J Infect Dis 149, 558-561.

Taylor, R. W., Manganaro, L., O'Brien, J., Trottier, S. J., Parkar, N. \& Veremakis, C. (2002). Impact of allogenic packed red blood cell transfusions on nosocomial infection rates in the critically ill patient. Crit Care Med 30, 2249-2254.

Uchida, T., Yamagiwa, A. \& Nakamura, K. (1991). The effect of interleukin-1 on iron metabolism in rats. Eur J Haematol 46, 1-5.

van Heyningen, W. E. (1955). The role of toxins in pathology. In Mechanisms of Microbial Pathogenicity (Society for General Microbiology Symposium no. 5), pp. 17-39. Edited by J. W. Howie \& A. J. O'Hea. Cambridge: Cambridge University Press.

Vincent, J.-L., Chierego, M., Struelens, M. \& Byl, B. (2004). Infection control in the intensive care unit. Expert Rev Anti Infect Ther 2, 795-805.

Wang, C., Schwaitzberg, S., Berliner, E., Zarin, D. A. \& Lau, J. (2003). Hyperbaric oxygen for treating wounds, a systematic review of the literature. Arch Surg 138, 272-279.

Ward, C. G. \& Bullen, J. J. (1999). Clinical and physiological aspects. In Iron and Infection. Molecular, Physiological and Clinical Aspects, 2nd edn, pp. 369-450. Edited by J. J. Bullen \& E. Griffiths. Chichester: Wiley. 